

DOI: $10.31636 /$ pmjua.t2.3

\title{
Частота експресії антигену CD 117 на бластних клітинах при мієлодиспластичному синдромі (МДС), гострій мієлоїдній лейкемії (ГМЛ)
}

\author{
Стародуб Г. С., Горяїнова Н. В., Треяк Н. М., Гордієнко А. І., Перехрестенко Т. П., \\ Кубарова В. О. \\ ДУ "Інститут гематології та трансфузіології НАМН України", Київ, Україна
}

CD 117 (kit) $є$ рецепторною тирозинкіназою типу III, яка бере участь у клітинній сигнальній трансдукції клітин. Зазвичай kit активується шляхом зв'язування його ліганду, запускаючи каскад фосфорилювання, призводячи до транскрипції в клітинах різного типу. Така активація регулює апоптоз, диференціацію, проліферацію клітин.

Мета. 3 огляду на те, що мієлодиспластичний синдром (МДС) - це клонова патологія з високою здатністю до трансформації у ГМЛ, $\epsilon$ актуальним вивчати експресії антигену CD 117 у хворих на МДС РАНБ I, РАНБ ІІ, ГМЛ.

Матеріал і методи. Проаналізовано дані 12 хворих на МДС, із них 7 РАНБ I та 5 з РАНБ ІІ i 11 хворих на ГМЛ, методом проточної лазерної цитофлюориметрії на FACScan (Becton Dickinson, США) з використанням програми LYSYS-II ver. 1.1 (Becton Dickinson, США).
Результати досліджень. Експресія антигену CD 117 визначена у 28,6\% обстежених хворих на МДС РАНБ І з показником $\mathrm{CD} 34^{+} 5,1 \pm 0,5 \%$ при 7,5 $\pm 1,5$ бластних клітинах у КМ, у хворих на МДС РАНБ II експресія CD 117 антигену спостерігалась у 80\% випадків при наявності $16,4 \pm 1,5 \% \mathrm{CD} 34^{+}$ бластних клітин у КМ. У хворих на ГМЛ de novo в КМ виявлялось $62,4 \pm 6,4 \%{\mathrm{CD} 34^{+}}^{+}$ бластних клітин, встановлено експресію CD 117 на 59,5 \pm 4,5\% клітин у $81 \%$ обстежених хворих.

Висновки. Динаміка експресії антигену CD 117 на бластних клітинах при МДС свідчить про активність патологічного процесу.

Ключові слова: МДС, гостра мієлоїдна лейкемія, антиген $\mathrm{CD} 117$. 